\title{
СИГНАЛ ШУУГИАНЫ ЧАДЛЫН СПЕКТРИЙГ ТОДОРХОЙЛОХ
}

\author{
Л.Тунгалаг, Ч.Баярсайхан \\ ШУА-ийн Одон орон, геофизикийн судалгааны төв, Улаанбаатар-51/152, Монгол \\ Цахим шуудан: иaа_lkh@yahoo.com
}

\section{ТОВЧ АГУУЛГА}

Уул уурхайн гаралтай тэсэлгээнээс бий болсон сейсмо-акустик сигнал нь “Инфра авианы” станцыг суурилуулсанаас хойш тасралтгүй бүртгэгдэж байна. Сейсмик болон сейсмо-акустик сигналыг хамтруулан боловсруулж, мэдээллийн санд анализ хийснээр тухайн тэсэлгээний эхэлсэн хугацаа, газар зүйн байршил, зай, чиглэл зэрэг параметрүүдийг тодорхойлдог.

Инфра авианы станцад өвөл болон зуны улиралд уурхайгаас ирэх тэсэлгээний акустик сигнал нь харилцан адилгүй бүртгэгдэж байсан. Энэхүү ажлаар харилцан адилгүй бүртгэгдэх шалтгааныг тодорхойлохын тулд сигналын спектрийн түвшинг магадлалаар тодорхойлох аргазүй боловсруулсан. Бидний хийсэн судалгаагаар инфра авианы станцад бүртгэгдэж байгаa акустик долгионы шуугианы түвшин өвлийн улиралд 25-30дБ байхад зун нь 30-40дБ болж нэмэгдэж байлаа. Энэхүү шуугианы түвшингийн өвөл, зуны улиралын ялгаа нь тэсэлгээний сигнал бүртгэх түвшинд нөлөөлөх гол параметр болох нь тодорхойлогдсон болно.

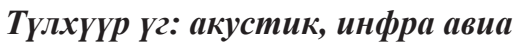

\section{СУДАЛГААНЫ ЗОРИЛГО}

Цөмийн дэлбэрэлтийг хянах дэлхийн 60 сүлжээ станц байгуулах ажлын хүрээнд Монгол улсад I34MN инфра авианы станцыг байгуулсан. Станцыг 2000 оны 10 сард Улаанбаатараас баруун урд зүгт өргөрөгийн $47.8017^{0}$, уртрагийн $106.4100^{\circ}$ солибицолд суурилуулсан. Инфра авианы станцын ажиглалтаар сүүлийн үед өргөн хүрээнд гүйцэтгэж буй судалгааны ажлын нэг чиглэл бол агаар мандлын орчинд хүний үйл ажиллагаатай холбоотой болон байгалийн гаралтай нам давтамжийн дуу үүсгэгч болон тэдгээр үүсгүүрүүдийг олж тогтоох явдал юм.

Сейсмик болон Инфра авианы станцаас 40-500 км зайд, даваагаас-баасан гаригийн, өдрийн $\quad 03.00-08.00$ (GMT) цагийн хооронд уул уурхайн тэсэлгээнүүд байнга бүртгэгдэж байдаг. Мэдээлэл боловсруулалтын явцад тэсэлгээнээ үүсэх дууны долгионы мэдээлэл нь өвлийн улиралд харьцангуй сайн бүртгэгдэж, зуны улиралд буурсан байгаа нь ажиглагдсан. Тэсэлгээнээс үүссэн акустик сигнал агаар мандлаар тархахдаа агаарын темпратур болон салхи зэрэг(McKenna, 2005; Golden et.al.2007) хүчин зүйлүүдээс хамаардаг байна.

Станцад бүртгэгдсэн автомат бльютений нэг жилийн мэдээллээр тэсэлгээний сигнал болон тухайн үеийн орчны шуугианыг харьцуулан спектрийн анализ хийсэн. Судалгааны гол зорилго нь станцын мэдээлэл бүртгэх байдал 
харьцангуй байгаа нь тэсэлгээний хүч, голомтын зай, бүс нутгийн цаг агаарын онцлог, салхины чиглэл болон салхины хурд зэрэг хүчин зүйлүүдээс хэрхэн хамааралтай болохыг тодорхойлох юм.

\section{ОНОЛ АРГА ЗУЙ}

Агаар мандалд дууны долгион тархахад агаарын температур болон салхи зэрэг хүчин зүйлс ихээхэн нөлөөтэй. Өөрөөр хэлбэл агаар мандлын температур, салхины хурд, салхины чиглэл нь өндрөөс хамааран өөрчлөгддөг тул инфра авианы

$$
V_{\text {sound }} \approx 331.4+0.6 T_{c}
$$

Энд: $\quad V_{\text {sound }}-$ дууны хурд

$$
T_{c} \text { - Tемператур }\left({ }^{\circ} \mathrm{C}\right)
$$

Агаар мандалд дууны долгион эффектив хурдаар тархдаг. Энэ хурд нь тархах хурд өргөн зурваст хэлбэлздэг [Garce's et al 2001].

$20^{\circ} \mathrm{C}$ агаарт дууны долгионы хурд ойрорлцоогоор 343 м/сек хурдтайгаар тархдаг ба агаарт дууны хурдны тархах томьёо:

$$
C_{e f f}=\sqrt{\gamma_{g} R T}+n * u
$$

дууны долгионы тархалтын хурд болон тархалтын чиглэлээр тодорхойлогдоно.

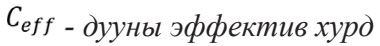

$\sqrt{\gamma_{g} R T}$ - агаар дахь хийн тогмол

$T$ - абсалют температур

n - долгионы тархалтын чиглэл дэхь нэгж вектор

и - салхины хурдны вектор

Инфра авианы долгион нь газрын гадаргуу болон термосферийн доод болон дээд үе давхаргуудаас ойх замаар дууны долгион нь энерги алдахгүйгээр хангалттай хол зайд хүрч чадах бөгөөд долгионы

$$
c=29.07 T^{1 / 2}
$$

Энд: Т- абсолют температур

Байгалын үзэгдэл, ан амьтад болон хүний үйл ажиллагаанаас үүсгэгдэх инфра авианы долгионыг бүртгэн авснаар тархах тархалтын шинж чанар, чиглэлээс үл хамаардаг байна [Rind,D, Donn,W 1973].

Инфра авианы дууны долгион идеал хийд, салхины нөлөөлийг тооцоогүй үед:

шинж чанар, зүй тогтолыг нарийн судлах шаардлагатай.

\section{МЭДЭЭЛЭЛ БОЛОВСРУУЛАЛТ}

Бүртгэгдсэн мэдээллийг MATLAB орчинд хийгдсэн PMCC [Cansi, 1995]програмыг ашиглан автомат анализ хийж, өндөр (НF 0.1-4Гц), нам (BF 0.001-0.1Гц), гравити долгион (GW 0.0001-0.05Гц) гэсэн 3 давтамжийн зурваст бюллетенийг үүсгэдэг. 
Үүссэн бюллетенээс давтамж, чиглэл, уурхайн тэсэлгээ, буудлаг г.м) бүртгэгдэж хурд, хугацааны хувьд анализ хийсэнээр байгааг харах боломжтой болдог (Зураг 1). ямар мэдээлэл (микробаромс, хотын чимээ,

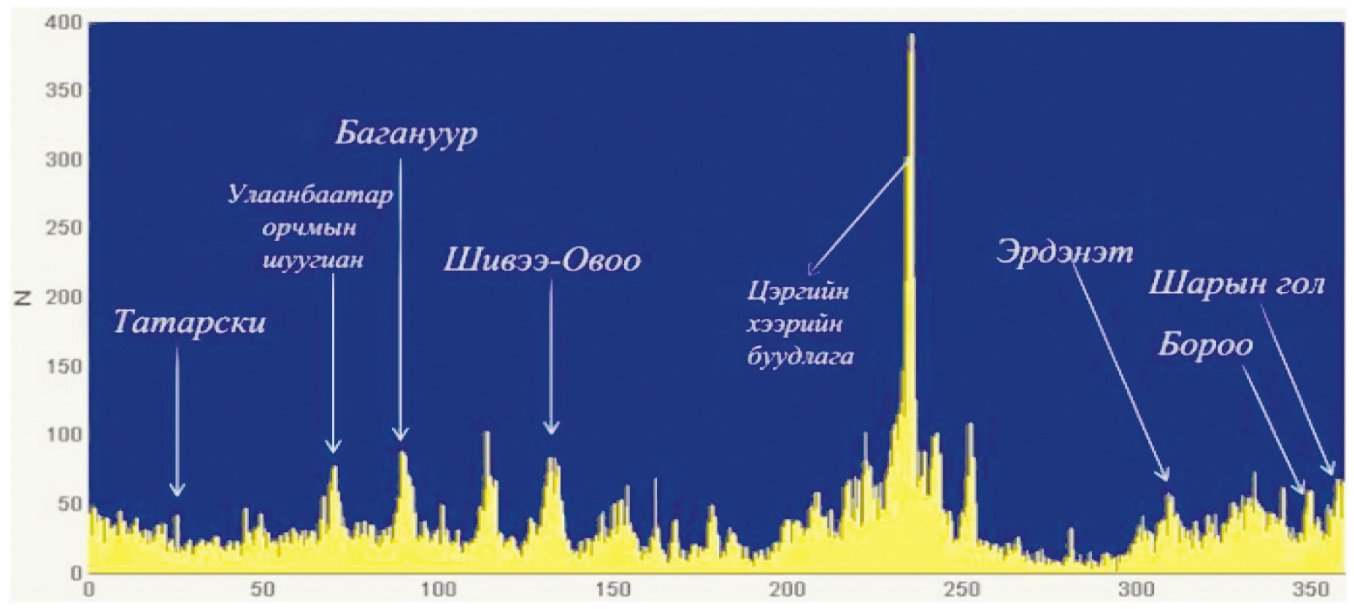

Зураг 1. 0.5-4Ги-ийн давтамжийн мужид бүртгэгдсэн мэдээлэл 2000-2009

Тэсэлгээ болон газар хөдлөлтийн боловсруулж долгионы тархах хурд, сигналыг хооронд нь ялгахад төвөгтэй байдаг. Сигналуудыг хооронд нь ялгахын тулд инфра авианы станцад бүртгэгдсэн мэдээллийг ашигладаг. Бүртгэгсэн мэдээллийг Win-PMCC програмаар давтамж, ирэх чиглэл зэргийг нь тодорхойлдог. Мөн зайнаас хамаарч тэсэлгээнээс үүссэн дууны долгионы туулж ирэх хугацааг тооцоолдог.
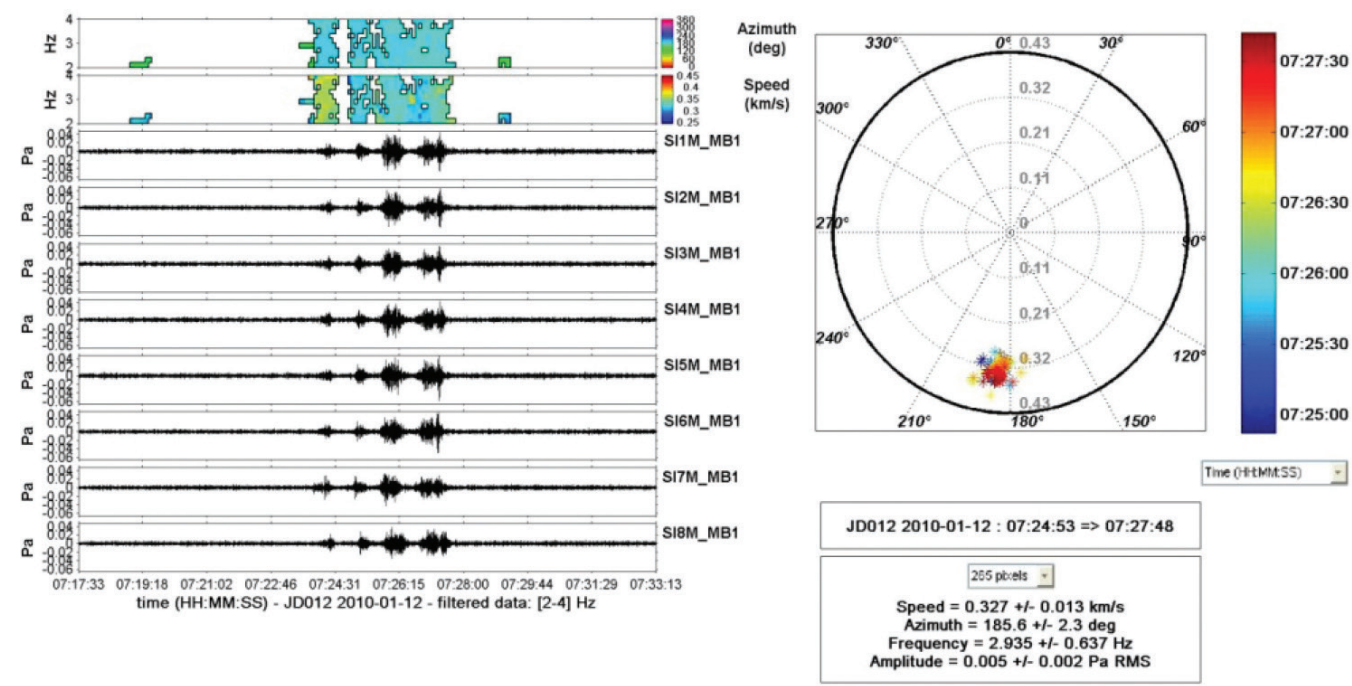

Зураг 2. Инфра авианы сигналын боловсруулалт 
Мэдээлэл боловсруулалтын ONYX програмаар сейсмик станцад бүртгэгдсэн мэдээллйг боловсруулснаар газар хөдлөлтийн газарзүйн байрлал, голомтонд эхэлсэн хугацаа, хүч болон гүнийг тодорхойлон гаргадаг. Тэсэлгээнээс үүссэн дууны сигналыг тэсэлгээний сейсмик сигналтай нь хамтруулан боловсруулснаар газар хөдлөлт болон тэсэлгээг хооронд нь ялгах боломжтой юм (зураг 3). Инфра авианы мэдээллийг ашиглан тэсэлгээг газар хөдлөлтөөс ялган тэсэлгээний мэдээллийн санг үүсгэж байна.

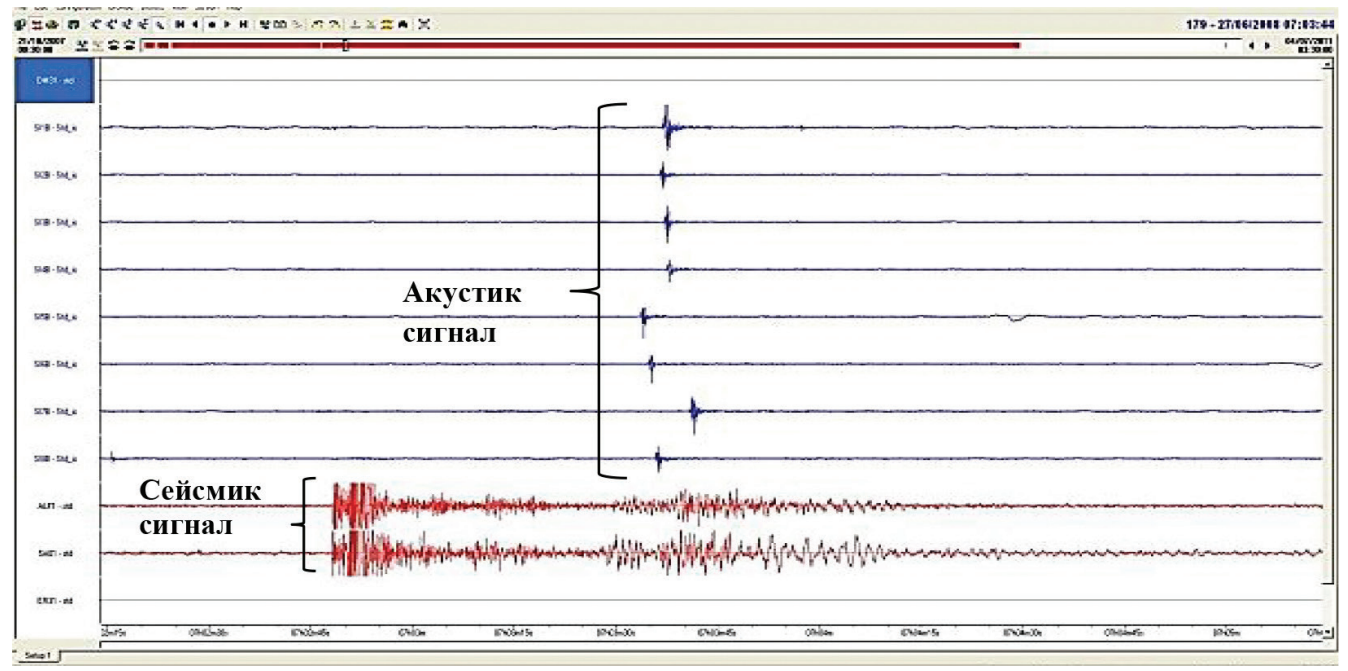

Зураг 3. Сейсмик болон инфра авианы сигналын хамтруулсан боловсруулалт

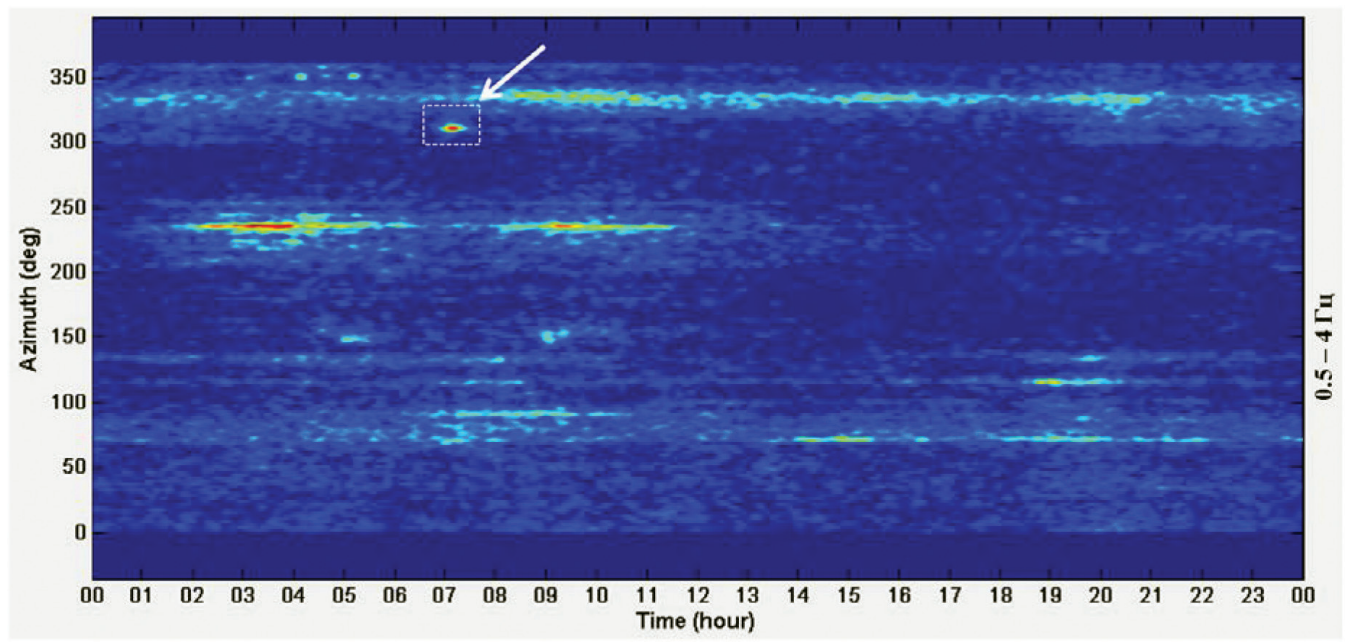

Зураг 4. 2000-2009оны хооронд 0.5-4 Ги давтамжийн мужид бүртгэгдсэн 69456 мэдээлэлд анализ хийсэн байдал

Тэсэлгээнй мэдээллийн санг байгаa нь ажиглагдсан. Иймд 2000-2009 бүрдүүлэх үед инфра авианы станц дахь мэдээлэлүүд харилцан адилгүй бүртгэгдэж оны бюллетенийг ашиглаад бүртгэгдэж байгаa чиглэлийг хугацаанаас нь 
хамааруулснаар өвлийн улиралд харьцангуй илүҮ мэдээлэл бүртгэгдэж байгаа зүй тогтолыг тодорхойлсон [Ч.Баярсайхан, 2009]. Станцын бүртгэх байдалд нөлөөлж буй хүчин зүйлийг тодорхойлохын тулд Эрдэнэтийн уурхайг сонгон авсан. Учир нь Эрдэнэтийн уурхай нь тогтмол хугацаанд тэсэлгээ хийдэг нь судалгааны ажилд нэн тохиромжтой нөхцлийг үүсгэж байна.

Эрдэнэтийн уурхай нь Улаанбаатар орчмын сейсмик станцуудаас баруун хойд зүгт ойролцоогоор 215 км зайд оршдог. Байр зүйн солбилцол нь GPS хэмжилтээр өргөрөгийн 49.0205, уртрагийн 104.1314 байна.

Эрдэнэтийн уурхайн тэсэлгээ нь сейсмикстанцад тогтмол 14:00-15:00 цагийн

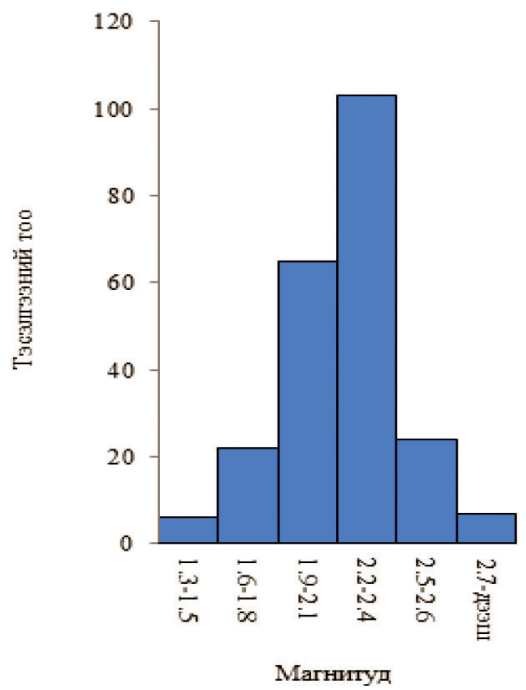

хооронд бүртгэгддэг бол тэсэлгээнээс Үүсэх дууны долгион нь Инфра авианы станцад 0.5-4Гц-ийн давтамжийн мужид, 0.290-0.310 км/с хурдтай бүртгэгдэж байна (зураг 4). Долоо хоногийн баасан гаригт 06-07 (UTC) цагийн орчим, 2-3 удаагийн давталттайгаар тэсэлгээ хийдэг. Зарим тохиолдолд мягмар гаригт тэсэлгээ хийдэг болох нь боловсруулалаар тодорхой болсон. Дулааны улиралд харьцангуй бага тэсрэх бодисыг хэргэлэснээр инфра авианы станц бүртгэж чадахгүй байна гэсэн таамаглалыг дэвшүүлсэн. Боловсруулалтаар тэсэлгээний хүчийг тооцоход магнитуд нь 1.6-2.6 байлаа. Иймд уурхайн тэсэлгээний хүчийг сарын дунджаар нь харьцуулсан дараах зүй тогтлыг гаргасан (зураг 5).

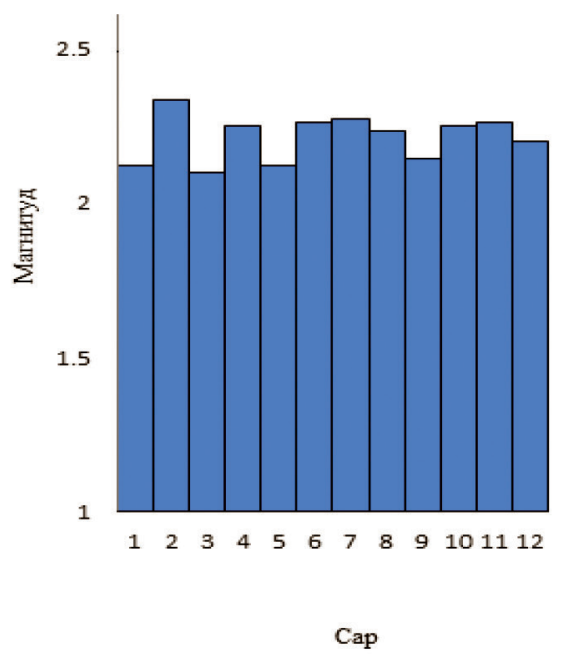

Зураг 5. Уурхайн тэсэлгээний хүчнийг тооисон гистограм

Харьцуулалтаас үзэхэд уухайн тэсэлгээ хийх давталт (долоо хоногийн

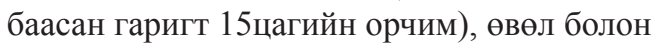
зуны улиралд тэсэлгээний хүч ойролцоо байгаа нь батлагдсан. Иймд инфра авианы станцын бүртгэх чадварт нөлөө үзүүлэхгүй нь харагдаж байна.

\section{ШУУГИАНЫ ЧАДЛЫН СПЕКТРИЙГ ТООЦОХ}

Манай орны ихэнх нутагт бараг жилийн турш баруун хойд, хойд, зүүн хойд чиглэлийн салхи $40-70 \%$ давталттай байдаг бол салхины жилийн дундаж хурд нь 2-3 м/с байдаг. Салхины бага хурд нь өвөл нэгдүгээр сард болон зун долдугаар сард ажиглагддаг байна. Станцын бүртгэх чадварт нөлөөлөхгүй байх зүй тогтолыг 
харуулж байна.

Станцын харилцан адилгүй бүртгэгдэх шалтгааныг тодорхойлохын

тулд сигналын спектрийн түвшинг магадлалаар тодорхойлох аргазүйг боловсруулсан. Сейсмик болон инфра авианы станцад бүртгэгдсэн 2009 оны Эрдэнэтийн уурхайн тэсэлгээний мэдээллийг ашигласан. Тэсэлгээнээс үүссэн акустик сигналыг сонгон авч бүртгэгдсэн сигналын өмнөх шуугианы түвшин болон дараах шуугианы түвшинг ашиглан сар тус бүрээр нь шуугианы чадлын спектрийг харьцуулан гаргасан (Зураг 6). Энд спектрийн нягтаршилын дундаж болон бүх тооцоо хийгдсэн шуугианы спектрийн 5-95\% интарвалыг харуулсан болно.
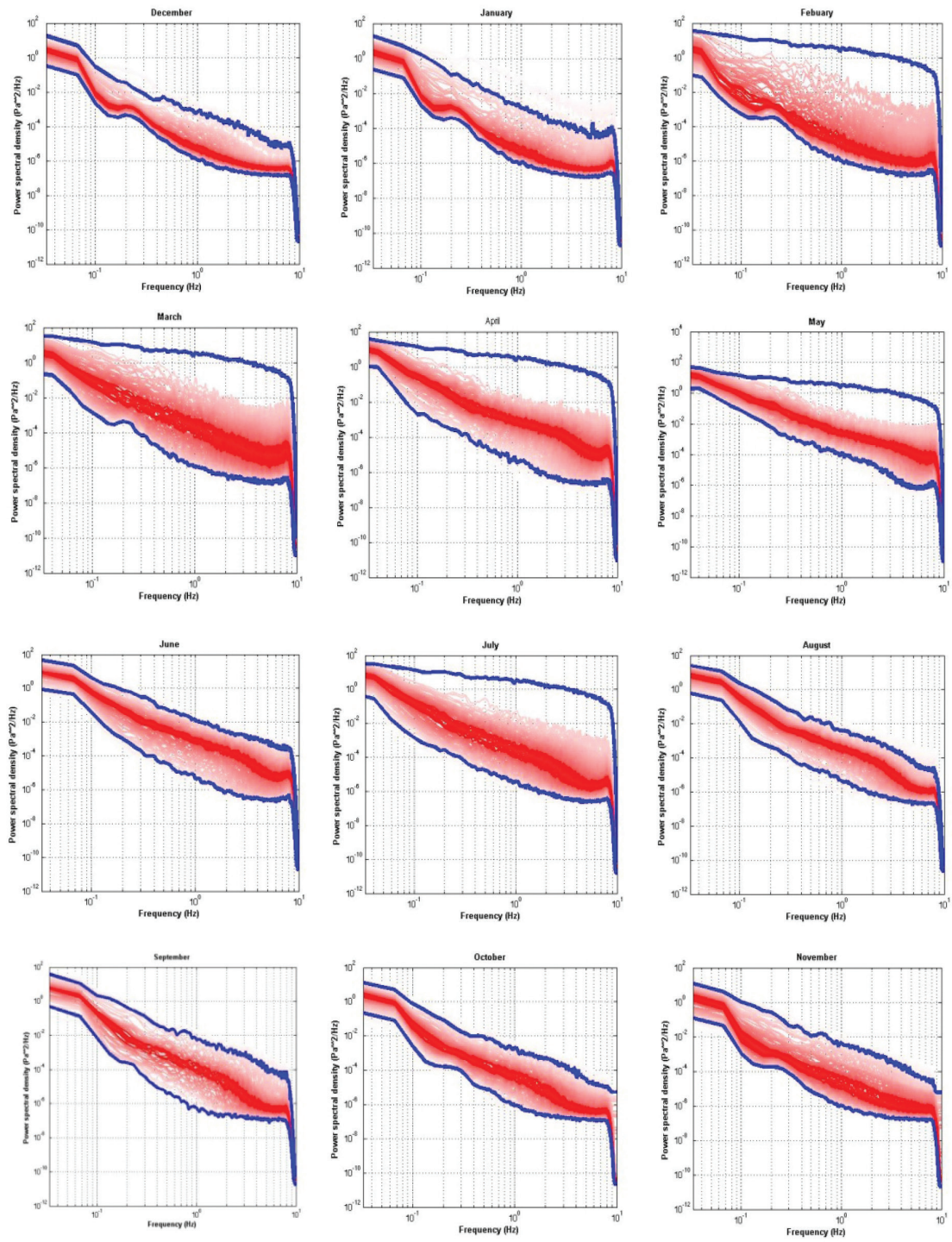

Зураг 6. Сар тус бүрд тооисон шуугианы чадлын спектр 
Орчны шуугианы түвшин өвөл болон зуны улиралд хэрхэн өсч буурч байгааг тодорхойлохын тулд нэгдүгээр сар болон долдугаар сарын шуугианы түвшинг хооронд нь харьцуулсан (зураг 6). Харьцуулалтаас өвлийн буюу нэгдүгээр сарын шуугианы дундаж түвшин 0.5-2 Гц, дулааны улиралд шуугианы дундаж түвшин 10дБ нэмэгдэж байна. Харьцуулалтаас үзэхэд дулааны улиралд шуугианы түвшин өссөн байгаа нь харагдаж байна.

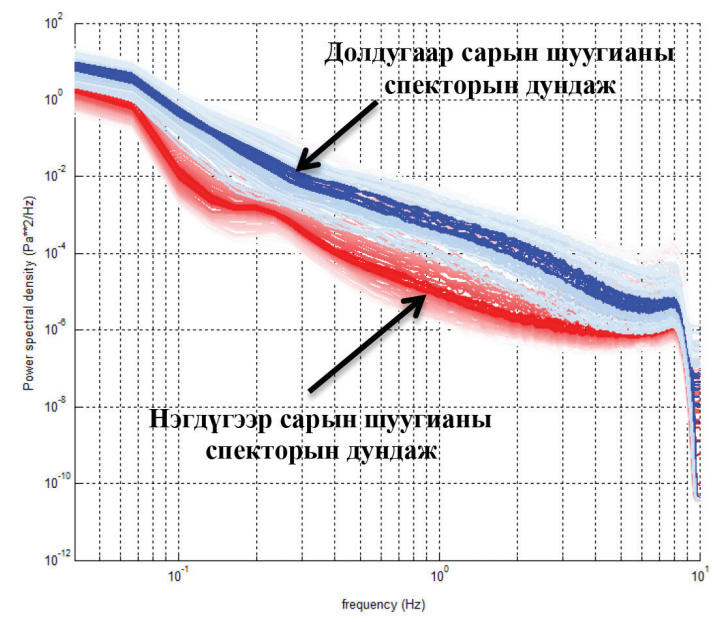

Зураг 7. Нэг болон долдугаар саруудын шуугианы чадлын спектрийн харьиуулалт

Тэсэлгээнээс үүссэн акустик сигналын бүртгэгдэх давтамж нь ойролцоогоор 0.9-5 Гцбайна.Инфраавианыстанцадбүртгэгдсэн Эрдэнэтийн уурхайн тэсэлгээнээ үүссэн акустик сигналыг улиралаас нь хамааруулаад сигнал-шуугианыг харьцуулсан (зураг 8). Судалгааны үр дүнд улирлын өөрчлөлтийн хувьд тодорхой ялгаа гарч байгааг тогтоолоо.

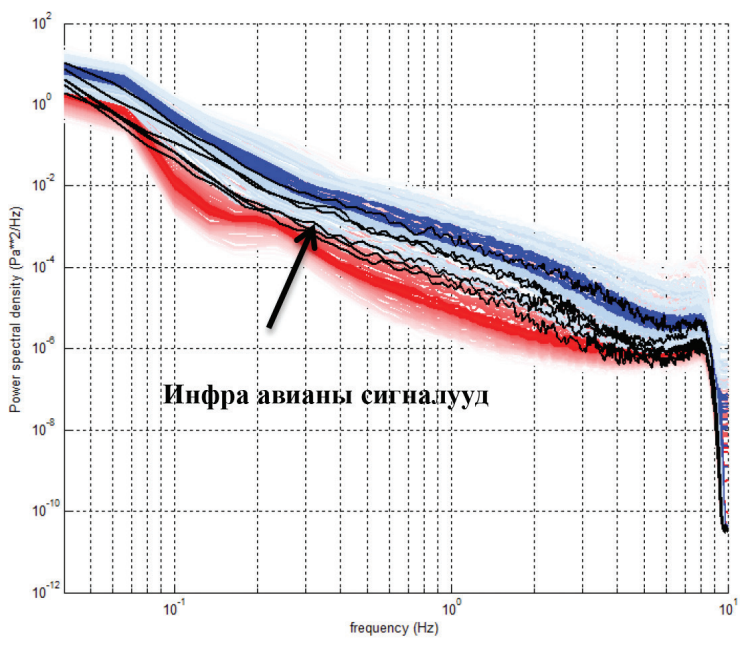

Зураг 8. Шуугианы түвшин болон инфра авианы сигнальн харьиуулалт 


\section{ДҮГНЭЛТ}

Сейсмик станцад бүртгэгдсэн байдлаар Эрдэнэтийн уурхай жилд 48-54 удаагийн тэсэлгээ хийсэн ба энэхүу тэсэлгээнээс үүсэх акустик долгионыг инфра авианы станц улиралаас хамааран харилцан адилгүй бүртгэсэн байна. Судалгааны явцад мэдээллийг харилцан адилгүй бүртгэж байгаа нь тэсэлгээний газарзүйн байрлал, тэсэлгээний хүчнээс хамаарахгүй харин орчны шуугианы түвшнээс хамаарч байгааг тодорхойлсон.

Судалгааны үр дүнд өвлийн улиралд шуугианы түвшин багасаж 25-30 дБ болсон бол зун нь 30-40дБ болж нэмэгдсэн байна. Зуны улиралд шуугианы түвшин нэмэгдэж байгаа тул тэсэлгээнээс үүсэх дууны долгион нь орчны шуугианаас давж гарч чадахгүй байна гэсэн дүгнэлтэнд хүрсэн.

Улиралаас хамааруулан шуугианы чадлын спектрийн харьцаа харилцан адилгүй байх бөгөөд өвлийн улиралд $0.5-4 Г ц$ давтамжийн мужид тэсэлгээний сигналыг бүртгэгэх бол зуны улиралд энэ мужид бүртгэгдэхгүй байх зүй тогтлыг тогтоосон болно.

Аиигласан бүтээлийн жагсаалт

1. Cansi, Y. (1995). "An automatic seismic event processing for detection and location: The PMCC method" Geophys. Res. Lett. 22, 1021-1024.

2. Cansi, Y. (1997). "An automated data processing method for mini-arrays" CSEM/ EMSE European-Mediterranean Seismological Centre, News Letter 11, 1021-1024.

3. Garce's, M., Hansen, R., Lindquist, K., Drob D., Picone, M. (1999). "Variability of the lower atmosphere and its effect on the propagation of infrasonic waves" Proceedings of the 21st Annual Research Symposium: Technologies for Monitoring the comprehensive Nuclear-Test-Ban Treaty, 21-24 September 1999, Las Vegas, Vol. 2, pp. 105-111. Sponsored by the US DoD and DoE, LA-UR-99-4700.

4. Le Pichon, A., Cansi, Y. (1999). "One-year analysis of systematic detection and location of infrasound in a prototype CTBT station, ”Acustica 85, Suppl. 1!, 178.

5. Rind, D., Donn, W.L., and Dede, E. (1973). "Upper air wind speeds calculated from observations of natural infrasound," J. Atmos. Sci. 30, 1726-1729.

6. Ch. Bayarsaikhan., A. Le Pichon., M. Ulziibat., Schlupp, A (2001). "Seismo-Acoustic data analysis at I34MN Mongolia-Songino" Infrasound Technology Workshop, Netherland Nov 2001

7. Л.Тунгалаг (2011). “Инфра авиаь станщад бүртгэгдсэн дуунь ҮҮсгүҮрҮҮдийг тодорхойлох"

8. Ч.Баярсайхан., (2013). “Инфра авиа тархалтын зүй тогтольг I34MN станцаар сайжруулан судалсан сейсмо акустик анализ” PhD диссертаци, x124-128 


\begin{abstract}
Seismic and acoustic recordings are particularly important to help identifying and locating industrial blasting sources. We have analyzed seismo-acoustic signals from mine blast for 2000 and 2009. Infrasound station observation result shows different detection level in winter and summer time. In order to determine this seasonal variation, we applied probabilistic spectral analysis for infrasound data. We found infrasound signal average spectral level in winter time has $25-30 \mathrm{~dB}$ and summer time $30-40 \mathrm{~dB}$. Consequently, this seasonal spectrum level difference is influencing detection level of infrasound station.
\end{abstract}

